Research Article

\title{
Prevalence of anemia among adolescent girls residing in rural field practice area of M. R. Medical College, Kalaburagi, Karnataka, India: a cross-sectional study
}

\author{
Shweta R. Chapparbandi*, S. R. Nigudgi \\ Department of Community Medicine, Mahadevappa Rampure Medical College, Kalaburagi, Karnataka, India
}

Received: 24 June 2016

Accepted: 12 July 2016

\section{*Correspondence:}

Dr. Shweta R. Chapparbandi,

E-mail: shwetachapparbandi@gmail.com

Copyright: (c) the author(s), publisher and licensee Medip Academy. This is an open-access article distributed under the terms of the Creative Commons Attribution Non-Commercial License, which permits unrestricted non-commercial use, distribution, and reproduction in any medium, provided the original work is properly cited.

\section{ABSTRACT}

Background: A large variety of morbidities such as nutritional deficiency disorders (stunting, wasting), menstrual disorders, etc. prevail among adolescents. They make nearly one tenth of Indian population and form a crucial segment of the society. Their current nutritional status will decide the wellbeing of the present as well as the future generations. Under-nutrition among these girls was associated with reduced lean body mass, lack of muscular strength and decreased work capacity and obstetric complications. Anemia is common during adolescence due to demands of increased growth and menstrual blood loss. Studies have shown that iron deficiency exists in both clinical as well as subclinical forms in adolescent girls. In adolescent girls, the onset of menstruation can alter the iron status of an individual not only by creating a demand for more iron due to blood loss but also due to the pro-inflammatory nature of menstrual cycle itself.

Methods: A cross-sectional study was carried out from January to December 2012. House to house survey was conducted; a pre-structured and pre-tested questionnaire was administered to all the adolescent girls of 10-19 years in the study area.

Results: Majority of girls 121 (38.05\%) were in high school; Majority of adolescent girls 132 (41.51\%) belong to class IV; Out of 318 adolescent girls, 200 (62.89\%) had attained menarche at the time of study; Majority of adolescent girls $176(55.35 \%)$ were moderately anaemic, followed by 15 (4.72\%) were having severe anemia, 13 $(4.09 \%)$ were having mild anemia.

Conclusions: Anemia is one of the health problems adolescent girls are facing in rural area.

Keywords: Adolescent girls, Anemia, Rural area

\section{INTRODUCTION}

Adolescents have always remained in a dilemma, as they are neither considered children nor adults. A similar fate seems to follow the development of a comprehensive policy on Adolescent Reproductive and Sexual Health (ARSH) in India mainly due to lack of inter-ministerial collaboration, socio-cultural and politico-religious factors. ${ }^{1}$
A study done by Geetha Joseph et al on General and Reproductive Health of Adolescent Girls in Rural South India (Tamil Nadu) found that headaches, body pains, and fatigue as common physical problems. ${ }^{2}$ A few cases mentioned weight loss, domestic problems, alcoholism in fathers and family conflicts were reported. Adolescents who were prevented by the family to study further, had various degrees of anxieties. Menstrual irregularities were most prominent among the adolescent while a few had white discharge. There was a general reluctance to 
discuss intimate personal, sexual and reproductive health issues in the group but felt more free to talk about general health and nutrition related topics. Most adolescents expressed the need for a separate clinic run only by women doctors and were against combining such services with maternal and child health clinics. During focus group discussions the mothers felt that the adolescents to be in good health but concurred with the common health problems.

A study done by D. Gunasekaran et al on Iron stores and menstruation in healthy adolescent girls in Pillaiyarkuppam, Puducherry found that Serum ferritin levels were significantly high in girls who had attained menarche compared to girls who have not attained menarche. ${ }^{3}$ There was no significant difference in the haemoglobin and serum iron levels between the two groups. Serum ferritin levels are elevated in healthy menstruating adolescent girls and care should be exercised in relying on ferritin alone for determination of iron status in these girls.

\section{METHODS}

Study area: This study was carried in rural field practice area Hebbal of Department of Community Medicine, M. R. Medical College, Gulbarga, Karnataka.

Study population: The study population includes all adolescent girls aged $10-19$ yrs.

Study design: The study was cross-sectional

Study duration: This study is carried out from January 2012 to December 2012.

Sample size: The population of rural field practice areaHebbal is 3,155 and population of adolescent girls is $9.9 \%{ }^{4}$

$$
\begin{gathered}
\text { Sample size }(9.9 \% \text { of total population })= \\
\frac{9.9 \times 3155=312.34}{100}
\end{gathered}
$$

So approximately $=312$

Inclusion criteria: All adolescent girls (married and unmarried)

Exclusion criteria: Other than adolescent girls.

Method of data collection: A house to house visit was made and all adolescent girls aged 10-19 years were studied.

Data analysis: The statistical tests used are percentages and chi-square test. The statistical software SPSS 12 is used for the analysis of the data. There is no conflict of interest, this study is not funded. Ethical Committee Approval is sought.

\section{RESULTS}

Table 1 shows that majority of girls $121(38.05 \%)$ were in high school, followed by $91(28.62 \%)$ were in middle school, $71(22.33 \%)$ were in college, $23(7.23 \%)$ are in primary school and least $12(3.77 \%)$ were illiterate.

Table 1: Distribution of adolescent girls according to their level of education.

\begin{tabular}{|lll|}
\hline Education & \multicolumn{2}{l|}{ Adolescent girls } \\
& Number & Percentage \\
\hline Illiterate & 12 & 3.77 \\
\hline Primary school & 23 & 7.23 \\
\hline Middle school & 91 & 28.62 \\
\hline High school & 121 & 38.05 \\
\hline College & 71 & 22.33 \\
\hline Total & 318 & 100.00 \\
\hline
\end{tabular}

Table 2 shows that majority of adolescent girls 132 (41.51\%) belong to class IV, followed by $100(31.45 \%)$ in class III, $52(16.35 \%)$ in class V, $30(9.43 \%)$ in class II and least $4(1.26 \%)$ in class I respectively.

Table 2: Distribution of adolescent girls according to Socio economic status.

\begin{tabular}{|lll|}
\hline $\begin{array}{l}\text { Socio economic } \\
\text { status }\end{array}$ & Adolescent girls \\
\hline Class I & Number & Percentage \\
\hline Class II & 30 & 1.26 \\
\hline Class III & 100 & 9.43 \\
\hline Class IV & 132 & 31.45 \\
\hline Class V & 52 & 41.51 \\
\hline Total & 318 & 16.35 \\
\hline
\end{tabular}

Table 3 shows that out of 318 adolescent girls, 200 $(62.89 \%)$ had attained menarche and $118(37.11 \%)$ had not yet attained menarche.

Table 3: Distribution of adolescent girls according to menarche.

\begin{tabular}{|lll|}
\hline Menarche status & \multicolumn{2}{l|}{ Adolescent girls } \\
& Number & Percentage \\
\hline Attained & 200 & 62.89 \\
\hline Not attained & 118 & 37.11 \\
\hline Total & 318 & 100.00 \\
\hline
\end{tabular}

Table 4 shows that majority of adolescent girls 176 $(55.35 \%)$ were moderately anaemic, followed by 15 $(4.72 \%)$ were having severe anaemia, $13(4.09 \%)$ were having mild anaemia and $114(35.85 \%)$ were having normal haemoglobin percentage. 
Table 4: Distribution of adolescent girls according to haemoglobin.

\begin{tabular}{|lll|}
\hline Hb\% & Adolescent girls \\
\cline { 2 - 3 } & Number & Percentage \\
\hline Normal & 114 & 35.85 \\
\hline Mild & 13 & 4.09 \\
\hline Moderate & 176 & 55.35 \\
\hline Severe & 15 & 4.72 \\
\hline Total & 318 & 100.00 \\
\hline
\end{tabular}

\section{DISCUSSION}

The present study revealed that majority of adolescent girls 121 (38.05\%) were in high school, followed by 91 $(28.62 \%)$ were in middle school, $71(22.33 \%)$ were in college, $23(7.23 \%)$ are in primary school and least 12 $(3.77 \%)$ were illiterate. Similarly a study done by Amruta Swati Indupalli et al on adolescent girls found that 31 $(12.4 \%)$ were illiterates, $66(26.4 \%)$ had primary education, $92(36.80 \%)$ had secondary education and $61(24.4 \%)$ had higher education or were college going. ${ }^{5}$

The present study revealed that majority of adolescent girls $132(41.51 \%)$ belong to class IV, followed by 100 $(31.45 \%)$ in class III, $52(16.35 \%)$ in class V, $30(9.43 \%)$ in class II and least $4(1.26 \%)$ in class I respectively. Similarly study done by Ratna Majumdar et al on adolescent girls in Pune found that majority of them i.e. $120(49.4 \%)$ belonged to the lower middle social class. ${ }^{6}$

The present study revealed that majority of adolescent girls $176(55.35 \%)$ were moderately anaemic, followed by $15(4.72 \%)$ were having severe anaemia, $13(4.09 \%)$ were having mild anaemia and $114(35.85 \%)$ were having normal haemoglobin percentage. Similarly a study done by Goyle A et al on adolescent girls in Jaipur, Rajasthan revealed that $96.3 \%$ of the adolescent girls suffered from anaemia, $31.2 \%$ of whom had mild deficiency and $65.1 \%$ had moderate deficiency. ${ }^{7}$ Similarly another study done by H. R. Shivaramakrishna et al on adolescent girls in Kolar district revealed that Anemia was detected in $34.8 \%$ of adolescent girls. ${ }^{8}$

\section{CONCLUSION}

Anemia is one of the health problems adolescent girls are facing in rural area. Community based activities are required to improve the nutritional status of the adolescent girls. Health education and behavioral change communication to the girls help to overcome the anemia. Existing health infrastructure such as Sneha clinic need to be strengthened in an attempt to improve the hemoglobin levels.

\section{ACKNOWLEDGEMENTS}

Authors are thankful to Mr. Anil Kumar Biradar (Health Inspector) and Mr. Pradeep Sanmukh (Health Assistant) for assisting us in house-to-house visit and data collection.

\section{Funding: No funding sources}

Conflict of interest: None declared

Ethical approval: The study was approved by the Institutional Ethics Committee

\section{REFERENCES}

1. Chang SP. Promoting adolescent health and development in South-East Asia. Indian J Community Med. 2011:36(4):245-46.

2. Joseph GA, Bhattacharji S, Joseph A, Rao PSS. General and reproductive health of adolescent girls in rural south India. Indian J Pediatr. 1997;34:24245.

3. Gunasekaran D, Swapna K, Ventakesh C, Soundararajan P. Iron stores and menstruation in healthy adolescent girls: pilot study. Current Paediatrics Research. 2012;16(2):153-55.

4. World population prospects: 2004 revision and world urbanization prospects: the 2004 revision. Population division of department of economic and social affairs of the United Nations secretariat. Available at: http://esa.un.org/unpp.

5. Indupalli AS, Sirwar SB. A cross sectional study on demographic profile and role of education in adolescent girls. People's Journal of Scientific Research. 2011;4(1):19-22.

6. Majumdar R, Ganguli SK. A study of adolescent girls in Pune. Perspectives and Issues. 2000;23(2):95-104.

7. Goyle A, Prakash S. Iron status of Adolescent girls (10-15 years) attending a Government School in Jaipur City, Rajasthan, India. Indian Journal of Nutrition. 2009;15(1):205-11.

8. Shivaramakrishna HR, Deepa AV and Sarithareddy M. Nutritional status of Adolescent girls in Rural Area of Kolar District:a cross-sectional study. Al AMeen Journal Medical Science. 2011;4(3):243-46.

Cite this article as: Chapparbandi SR, Nigudgi SR. Prevalence of anemia among adolescent girls residing in rural field practice area of M. R. Medical College, Kalaburagi, Karnataka, India: a cross-sectional study. Int J Community Med Public Health 2016;3:2161-3. 